九州大学学術情報リポジトリ

Kyushu University Institutional Repository

\title{
Mode of Action of Clostocin 0: Part 1. On the Macromolecular Synthesis in Sensitive Bacteria
}

Kato, Fumio

Laboratory of Applied Microbiology, Faculty of Agriculture, Kyushu University

Yoshino, Sadazo

Laboratory of Applied Microbiology, Faculty of Agriculture, Kyushu University

Ogata, Se iya

Laboratory of Applied Microbiology, Faculty of Agriculture, Kyushu University

Choi, Kyoung Ho

Laboratory of Applied Microbiology, Faculty of Agriculture, Kyushu University

他

https://doi.org/10.5109/23659

出版情報：九州大学大学院農学研究院紀要. 22 (3)，pp. 133-143，1978-07. Kyushu University バージョン：

権利関係: 
J.Fac. Agr., Kyushu Univ., 22,133-143 (1978)

\title{
Mode of Action of Clostocin 0 Part 1. On the Macromolecular Synthesis in Sensitive Bacteria
}

\author{
Fumio Kato*, Sadazo Yoshino, Seiya Ogata \\ Kyoung Ho Choi and Shinsaku Hayashida \\ Laboratory of Applied Microbiology, Faculty of Agriculture, \\ Kyushu University 46-02, Fukuoka 812
}

(Received November 4, 1977)

\begin{abstract}
Clostocin 0 is a phage tail-like bacteriocin produced by Clostridium saccharoperbutylacetonicum (ATCC 13564). One particle of clostocin 0 had an activity to kill one sensitive organism. The biosynthesis of macromolecules (protein, RNA and DNA) in sensitive organism was inhibited by clostocin 0 infection. The amounts of macromolecules of the infected organism were held at the initial level. The fate of the macromolecules in clostocin O-infected organism was investigated by using of isotope labeled compounds. The permeability for glucose or phenylalanine was held for 15 min after clostocin 0 infection. The biosyntheses of lipid and protein were somewhat moderately inhibited within $15 \mathrm{~min}$ after clostocin 0 infection, whereas the biosyntheses of DNA and RNA were immediately inhibited after clostocin 0 infection. However, degradation of DNA was not observed. From these results, we suggest that clostocin 0 strongly inhibits the synthesis of nucleic acids in short time.
\end{abstract}

\section{INTRODUCTION}

Bacteriocins are bactericidal substances produced by certain strains of bacteria and are usually active against the same or closely related species. Their narrow activity spectra and protein nature distinguish them from most of the other known antibiotics. They are conveniently divided into two groups (Reeves, 1972), one is comparatively small protein composed of low molecular weight under 100,000 , and the other is made up of many protein components and shows phage tail-like structure.

The interest of bacteriocins in the molecular biology focuses mostly upon their characteristic mode of action. As yet, too few have been studied to generalize their mode of action. Bacteriocins, whose mode of action have made clear to date, are divided into 5 groups by their mode of action. The first group has colicin El and K (Jacob et al., 1952 ; Luria, 1964 ; Field and Luria, 1969), colicin A (Nagel de Zwaig, 1969) and colicin I (Levisohn et al. 1968) which inhibit energy metabolism. Namely, they inhibit the biosynthesis of macromolecules in consequence of the inhibition of oxidative phosphorylation. This group contains also phage tail-like bacteriocins, such as pyocin $\mathrm{R}$ (Kaziro and Tanaka, 1965) and pyocin 28 (Ohnishi, 1969). The second group

\footnotetext{
* Present address : Department of Agricultural Chemistry, Saga university, Saga
} 
has colicin E2 (Obinata and Mizuno, 1970 ; Ringrose, 1970) and megacin C (Holland, 1963 ; Holland, 1965) which inhibit DNA synthesis following DNA degradation. Recently, colicin E2 has been reported to be a endonuclease (Schaller and Nomura, 1976). The third group has colicin E3 (Nomura, 1964) and cloacin DF 13 (de Graaf and Stouthamer, 1969) which inhibit protein synthesis. Bowman et al. (1971 a), Bowman et al. (1971 b) and Senir and Holland (1971) reported that colicin E3 may penetrate into the sensitive organism and directly act on the ribosome of infected organism as a sort of endonuclease. The fourth group has pneumocin G196 (de Graaf and Stouthamer, 1970) which inhibits both protein and RNA synthesis. The fifth group has megacin A-216 (Holland and Roberts, 1964) and enterococcin (Brock and Davie, 1963 ; Davie and Brock, 1966) which affect the cytoplasmic membrane of infected organism and inhibit the active transport and also cause a cellular lysis as a sort of phosphatase or phospholipase.

Clostocin 0 is a phage tail-like bacteriocin of Clostridium sacchroperbutylacetonicum (Ogata et al., 1972) and one particle of clostocin 0 kills one sensitive organism after its adsorption to a specific receptor of the bacterial surface (Kato et al., 1976 ; Ogata et al., 1976). To make its mode of action clear, the metabolism of infected organism must be followed by using radioisotope labeled compounds.

This paper describes the effect of clostocin 0 on the biosynthesis of infected organism during short period after clostocin 0 infection. Further we attempt to know the mode of action of clostocin 0 .

\section{MATERIALS AND METHODS}

\section{Organisms}

The strains used were N 1-4 (ATCC 13564) and No. 8 of Clostridium saccharoperbutylacetonicum for producing and sensitive strain of clostocin 0 , respectively.

\section{Assay of clostocin 0}

The activity of clostocin 0 was assayed by the double-layer method. Two fold serial dilutions of clostocin 0 were prepared, and examined by the spot test (Ogata et al., 1972) on the sensitive organism. An arbitrary unit of activity (units $/ \mathrm{ml}$ ) was defined as the reciprocal of the highest dilution clearly showing an inhibition zone.

\section{Assay of survival organism}

The survival organisms infected by clostocin 0 were also assayed by doublelayer method. The plate culture was incubated in the anaerobic jar for 24 $\mathrm{hr}$ and the colony number was counted by a colony counter (Kanto Rikaki Ltd.).

\section{Labeled compounds}

${ }^{32} \mathrm{P}$ labeled $\mathrm{H}_{3} \mathrm{PO}_{4}$ was used for measurement of nucleic acid synthesis. Phenylalanine-U $-{ }^{14} \mathrm{C}$ was used for measurement of protein synthesis. Permeability and metabolism were investigated by using glucose-U-\%. ${ }^{32} \mathrm{P}$ labeled 
compound was purchased from the Japan Radioisotope Association and other compounds were purchased from Daiichi Radioisotope Lab. Ltd..

\section{Media and cultural conditions}

TYA medium (Ogata and Hongo, 1974) and minimum tnedium containing $2 \mathrm{~g} / 1$ of Casamino acids (CA-MM) (Kato et al. 1976) were used for the culture broth of the sensitive organism. Glucose, Casamino acids and $\mathrm{KH}_{2} \mathrm{PO}_{4}$ was respectively cut down to one-tenth amount of CA-MM, when glucose-U- ${ }^{14} \mathrm{C}$, phenylalanine-U $-{ }^{14} \mathrm{C}$ and ${ }^{32} \mathrm{P}$ were used. The sensitive organism preincubated in TYA medium was inoculated to $200 \mathrm{ml}$ of $\mathrm{CA}-\mathrm{MM}$ at 0.15 of $\mathrm{OD}_{660}$ and incubated until the $\mathrm{OD}_{650}$ reached at 0.3 under reduced atmospheric pressure (5 to 10 $\mathrm{mmHg}$ ). This culture broth was divided into equal volume of $90 \mathrm{ml}$ and continued incubation bubbling with high purity of $\mathrm{N}_{2}$ gas at $30^{\circ} \mathrm{C}$. A $10 \mathrm{ml}$ of 300 units of clostocin 0 was added to one culture and heated clostocin 0 (inactivated clostocin 0) was added to control culture. After $5 \mathrm{~min}$, radioisotope compound was added to both cultures $(0 \mathrm{~min})$. Then $4.5 \mathrm{ml}$ of culture broth was taken out at suitable intervals and the macromolecules of the organisms were fractionated by modified Schmidt-Thannhauser-Schneider (STS) procedure (Mizuno and Whitely, 1968). The production of clostocin 0 had been described in elsewhere (Ogata et al., 1972).

\section{Fractionation of cellular components}

The fractionation of macromolecules and other cellular components were performed by modified STS procedure. A $0.5 \mathrm{ml}$ of $50 \%(\mathrm{w} / \mathrm{v})$ trichloroacetic acid (TCA) was immediately added to $4.5 \mathrm{ml}$ of cell culture to stop the incorporation of radioisotopes. When further experiments were performed on this fraction, the organism was centrifuged immediately under cold, and then treated with cold TCA.

The fractionation of nucleotide and sugar phosphate ester was attempted from the cold acid soluble fraction by using treatment of activated charcoal (Norit A) reported by Leloir and Cardini (1957).

\section{Estimation of the amounts of some cellular components labeled by ${ }^{32} \mathrm{P}$}

The sensitive organism preincubated in TYA medium was inoculated at 0.15 of $\mathrm{OD}_{660}$ in $\mathrm{CA}-\mathrm{MM}$ reducing $\mathrm{KH}_{2} \mathrm{PO}_{4}$, then ${ }^{32} \mathrm{P}$ was added, and incubated at $30^{\circ} \mathrm{C}$ under reduced atmospheric pressure until $\mathrm{OD}_{560}$ became to be at 0.3 . The sensitive organism was harvested by centrifugation at $10,000 \times g$ for 15 min, and resuspended in fresh $200 \mathrm{ml}$ of CA-MM, then the culture was divided into two parts of $90 \mathrm{ml}$. The cultural condition and fractionation was performed as same as above mentioned.

\section{Measurement of radioactivity}

The radioactivity of ${ }^{14} \mathrm{C}$ and ${ }^{32} \mathrm{P}$ was counted by Aloka gas flow counter (model TDC-10).

\section{RESULTS}

\section{Single hit killing kinetics of clostocin 0}

Various concentrations of clostocin 0 were infected to the sensitive or- 
ganism at $30^{\circ} \mathrm{C}$ for $15 \mathrm{~min}$, and the survival numbers were detected by the double-layer method. As shown in Fig. 1, the concentration of clostocin 0 and logarithm of the survival ratio bears a liner relationship to each other. This result must indicate that the killing ability of clostocin 0 complies with a single hit theory. According to this single hit theory, one killing unit kills $36 \%$ of the organisms. From the result in Fig. 1, we are able to know that 3 units of clostocin 0 can kill $36 \%$ of the organisms. Three units of clostocin 0 are equal to $3 \times 10^{8}$ particles $/ \mathrm{ml}$ (Ogata et al., 1976). In the experiment of Fig. 1, we used $2 \times 10^{8} \mathrm{cells} / \mathrm{ml}$ of the sensitive organism. Therefore, 1.5 particles of clostocin 0 kill one organism. This fact indicates that the killing kinetics of clostocin 0 follows the single hit theory.

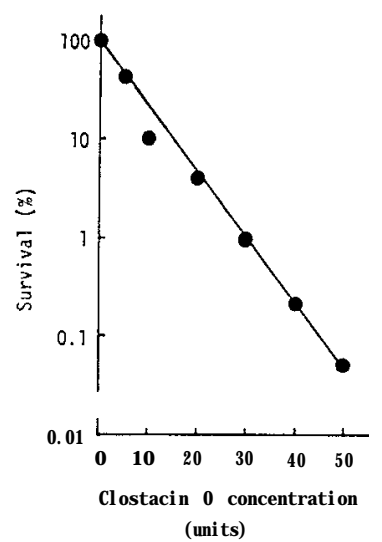

Fig. 1. Dependence of various concentrations of clostocin $O$ on its killing activity. Various concentrations of clostocin $O$ were infected to the sensitive organisms at $30^{\circ} \mathrm{C}$ for $15 \mathrm{~min}$. Survivors were counted by double-layer method.

\section{Inhibition of macromolecule biosynthesis by clostocin 0}

To know the influences of clostocin 0 on the biosyntheses of macromolecules in the sensitive organism, the amounts of the macromolecules were measured after clostocin 0 infection. The dose of clostocin 0 used for this experiment was enough to kill $95 \%$ or more of the sensitive organism which was grown in CA MM. As shown in Fig. 2, the amounts of protein, RNA and DNA were all kept at the initial level and did not change for $3 \mathrm{hr}$. This result indicates that the biosyntheses of these macromolecules are inhibited by clostocin 0 infection, and moreover, these substances are not degraded by clostocin 0 infection.

\section{Permeability of clostocin O-infected organism}

The uptake of ${ }^{14} \mathrm{C}$-glucose or ${ }^{14} \mathrm{C}$-phenylalanineby the clostocin $\mathrm{O}$-infected organism was measured at intervals of $5 \mathrm{~min}$ after addition of radioisotopes. Results are shown in Fig. 3. The uptake of ${ }^{14} \mathrm{C}$-glucose was not inhibited during early $10 \mathrm{~min}$ and the uptake of ${ }^{14} \mathrm{C}$-phenylalanine also continued for 15 min under reduced rate. These results indicate that the permeability of in- 

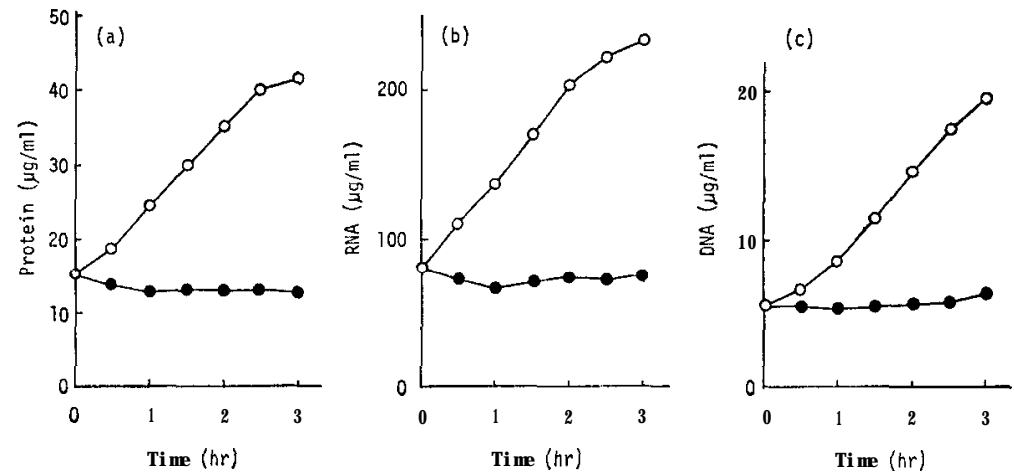

Fig. 2. Effects of clostocin 0 on macromolecules biosynthesis of infected organism. Sensitive organism was incubated in the minimum medium containing casamino acids and added 39 units of clostocin 0 at 0.3 of $\mathrm{OD}_{660}$. Ten $\mathrm{ml}$ of the culture broth was taken out at each 3 ? min intervals and fractionated by modified S'TS procedure. (a) protein, (b) RNA, (c) DNA. $\quad$, control (normal organism) ; $\bullet$, clostocin O-infected organ* ism.
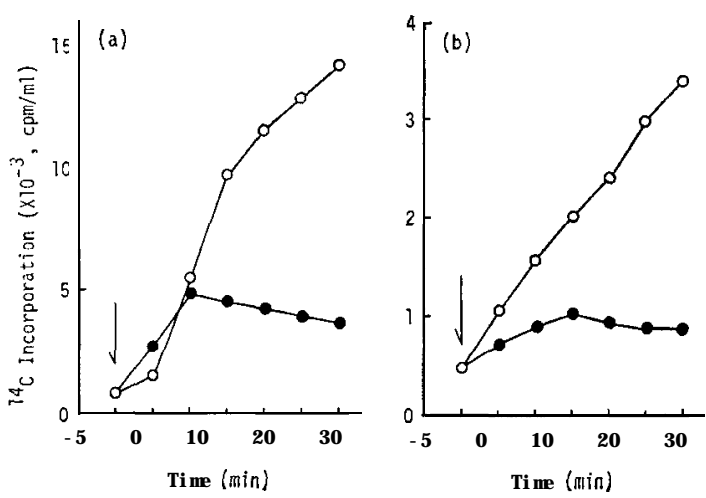

Fig. 3. Uptake of ${ }^{14} \mathrm{C}$-glucose and ${ }^{14} \mathrm{C}$-phenylalanine by clostocin $\mathrm{O}$-infected organism. The organism was incubated at $30^{\circ} \mathrm{C}$ with bubbling $\mathrm{N}_{2}$ gas. At 5 minafter infection of 30 units of clostocin 0 , radioisotope was added to the culture, as shown by the arrow. A $4.5 \mathrm{ml}$ of the culture was taken out at 5 min interval and chilled at each time. The organism was harvested by centrifugation at $3,000 \mathrm{rpm}$ for $10 \mathrm{~min}$ and was degradated with $0.3 \mathrm{~N}$ KOH. An amount of $0.5 \mathrm{ml}$ of sample was dried up in a planchette and radioactivity was measured by a gas flow counter. (a) uptake of ${ }^{14} \mathrm{C}$-glucose (final concentration of $0.5 \mu \mathrm{Ci} / \mathrm{ml}$ ), (b) uptake of ${ }^{14} \mathrm{C}$-phenylalanine (final concentration of $0.25 \& \mathrm{i} / \mathrm{ml}$ ). c. control (normal organism); • clostocin O-infected organism.

fected organism is not affected by clostocin 0 in the early stage of infection, and that the inhibition of macromolecule synthesis is not due to the decrease in permeability.

\section{Macromolecular synthesis in clostocin O-infected organism}

'The incorporation of radioisotopes into lipid, protein, RNA and DNA frac- 
tions was measured. As shown in Fig. 4 (a), ${ }^{32} \mathrm{P}$ incorporation into lipid fraction did not show a great difference between control and clostocin O-infected organism during early $15 \mathrm{~min}$. Incorporation of ${ }^{14} \mathrm{C}$-phenylalanine into protein fraction continued for $20 \mathrm{~min}$ in a reduced rate [Fig. 4 (b)]. However, as shown in Fig. 4 (c) and (d), the incorporation of ${ }^{32} \mathrm{P}$ into RNA and DNA fractions was strongly inhibited in the infected organism. These results indicate that clostocin 0 inhibits abruptly the synthesis of nucleic acid in the infected organism.

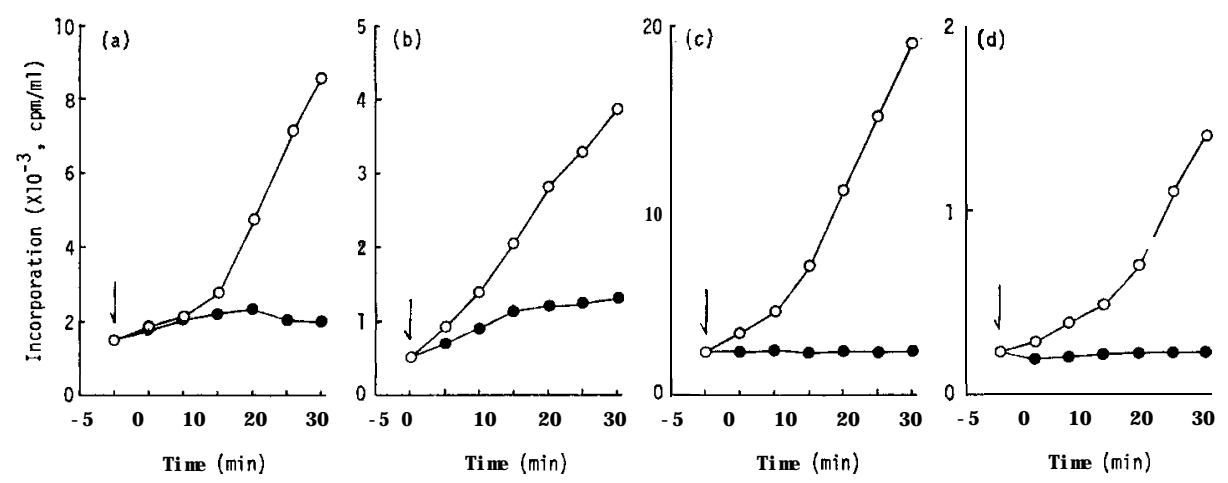

Fig. 4. Incorporation of radioisotopes into lipid, protein, RNA and D N A fractions after clostocin 0 infection. The cultural condition and symbols are the same as described in Fig. 3. The arrow indicates the time of addion of radioisotope. An amount of $4.5 \mathrm{ml}$ of the culture was withdrawn at $5 \mathrm{~min}$ interval and fractionated by the modified STS procedure. (a) Incorporation of $32 \mathrm{P}$ into lipid fraction (final concentration of ${ }^{32} \mathrm{P}$ $\mathrm{H}_{3} \mathrm{PO}_{4}$ was $2 \mathrm{\& i} / \mathrm{ml}$ ), (b) incorporation of ${ }^{14} \mathrm{C}$-phenylalanine into protein fraction (final concentration of ${ }^{14} \mathrm{C}$-phenylalanine was $0.25 \mu \mathrm{Ci} / \mathrm{mI}$ ), (c) incorporation of ${ }^{32} \mathrm{P}$ into RNA fraction (final concentration of ${ }^{32} \mathrm{P}_{-} \mathrm{H}_{3} \mathrm{PO}_{4}$ was $2 \mu \mathrm{Ci} / \mathrm{ml}$ ), (d) incorporation of $32 \mathrm{P}$ into DNA fraction (final concentration of ${ }^{32} \mathrm{P}_{-} \mathrm{H}_{3} \mathrm{PO}_{4}$ was $2 \mu \mathrm{Ci} / \mathrm{ml}$ ).

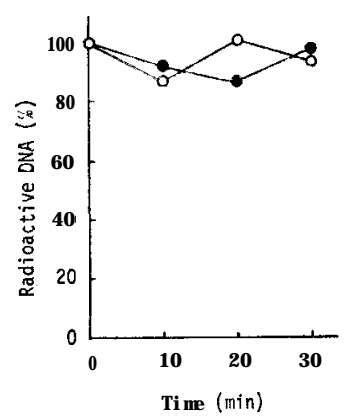

Fig. 5. Fate of 32 P-labeled DNA after clostocin 0 infection. The sensitive organism grown in $\mathrm{CA}-\mathrm{MM}$ with ${ }^{32} \mathrm{P}-\mathrm{H}_{3} \mathrm{PO}_{4}$ (final concentration of $2.5 \mu \mathrm{Ci} / \mathrm{ml}$ ) was harvested by centrifugation and resuspended in the fresh CA-MM without ${ }^{32} \mathrm{P}$. After infection of clostocin 0, a portion of culture was withdrawn at $10 \mathrm{~min}$ interval and fractionated by modified STS procedure. Symbols are the same as described in Fig. 3. 


\section{Fate of DNA in clostocin O-infected organism}

To determine whether clostocin 0 causes the degradation of DNA or not, following experiment was performed. Clostocin 0 was infected to ${ }^{32} \mathrm{P}$ labeled organism and the amounts of radioactive DNA were measured. As shown in Fig. 5, the amounts of radioactive DNA were almost the same in infected and uninfected organisms. So the significant degradation of DNA did not occur for $30 \mathrm{~min}$ after clostocin 0 infection. It is concluded that clostocin 0 inhibits the biosynthesis of nucleic acid but does not have the activity to degradate DNA like colicin E2 (Obinata and Mizuno, 1970).

Biosynthesis and degradation of organic phosphate compounds in clostocin O-infected organism

Clostocin 0 strongly inhibited the nucleic acid of sensitive organism. So it was considered that the effects of clostocin 0 on the biosynthesis and degradation of organic phosphate compounds had to be investigated as the next step. These substances can be detected in cold TCA soluble fraction as ${ }^{\mathbf{3 2}} \mathbf{P}$

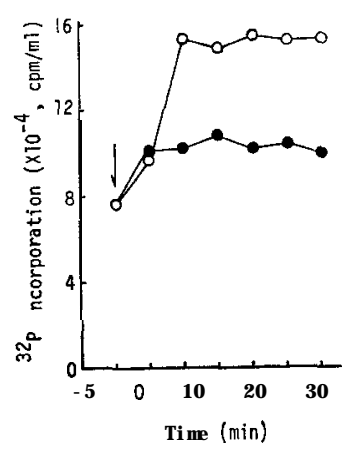

Fig. 6. Incorporation of $32 \mathrm{P}$ into cold TCA soluble fraction after clostocin 0 infection. Experimental conditions and symbols are the same as described in Fig. 3.

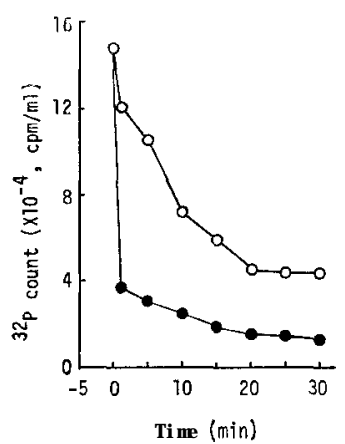

Fig. 7. Decrease of cold TCA soluble substances labeled with ${ }^{32} \mathrm{P}$ after clostocin 0 infection. Experimental conditions and symbols are the same as described in Fig. 3. 
compounds when ${ }^{32} \mathrm{P}$ was used. The changes of radioactivity between control and the infected organism were monitored in this fraction. The incorporation of ${ }^{32} \mathrm{P}$ into clostocin O-infected organism is shown in Fig. 6. And the decrease of radioactivity in the organism which had been labeled with ${ }^{32} \mathrm{P}$ is shown in Fig. 7. The incorporation of ${ }^{32} \mathrm{P}$ was repressed by clostocin 0 infection. The radioactivity of labeled organism was suddenly dropped by clostocin 0 infection.

As the cold TCA soluble fraction was considered to contain nucleotides and other phosphate compounds, mainly sugar phosphate esters, these compounds were separated with activated charcoal. The nucleotides were adsorbed to the activated charcoal, on the other hand, the sugar phosphate esters and others were not adsorbed: the radioactivities of each part were measured

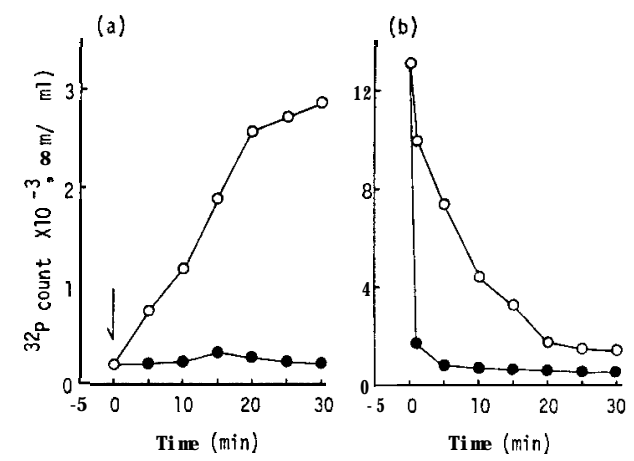

Fig. 8. Change in nucleotidc level after clostocin O infection. A $0.5 \mathrm{ml}$ of cold TCA soluble fraction was treated with activated charcoal and the charcoal-adsorbed fraction was measured its radioactivity by gas flow counter. (a) incorporation of ${ }^{32} \mathrm{P}$ labeled nucleotide, (b) decrease of ${ }^{32} \mathrm{P}$ labeled nucleotide. Symbols are the same as described in Fig. 3.

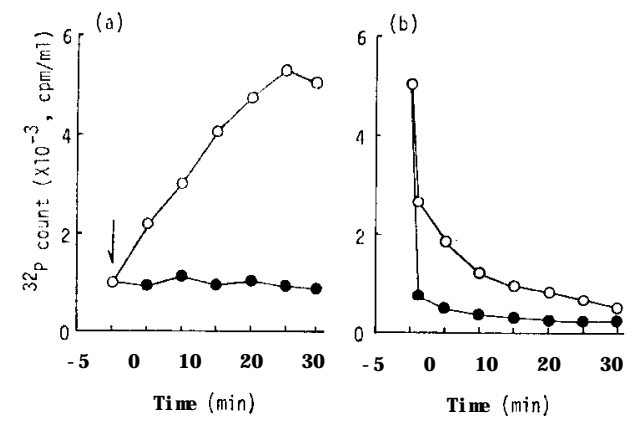

Fig. 9. Change in level of radioactivity in activated charcoal-unadsorbed fraction after clostocin 0 infection. A $0.5 \mathrm{ml}$ of cold TCA soluble fraction was treated with activated charcoal and the unadsorbed-fraction was measured its radioactivity by gas flow counter. (a) incorporation of ${ }^{32} \mathrm{P}$ into activated charcoal-unadsorbed fraction, (b) decrease of ${ }^{32} \mathrm{P}$ labeled substances. Symbols are the same as described in Fig. 3. 
as shown in Figs. 8 and 9. As shown in Fig. 8 (a), the incorporation of ${ }^{32} \mathrm{P}$ into nucleotides was remarkably inhibited by clostocin 0 infection. Also, Fig. 8 (b) indicates that the decrease of labeled nucleotides remarkably occurred within a short period by clostocin 0 infection. It is considered that the strong inhibition of nucleotide biosynthesis and the remakable release of nucleotide from clostocin O-infected organism may cause the inhibition of nucleic acid biosynthesis system. The changes of radioactivity in the substances unadsorbed by activated charcoal is shown in Fig. 9 (a). The incorporation of ${ }^{32} \mathrm{P}$ into sugar phosphate esters was strongly inhibited by clostocin 0 infection. And also the decrease of labeled substances in infected organism was larger than that of control as shown in Fig. 9 (b). Thus, it seems that the biosynthesis of sugar phosphate esters is strongly inhibited and the release of these substances from the infected organism is hastened by clostocin 0 infection.

\section{DISCUSSION}

The biosynthesis of nucleic acid of clostocin O-infected organism was strongly inhibited. But, their permeability and biosynthetic abilities of lipid and protein remained for 15 to $20 \mathrm{~min}$ after clostocin 0 infection. So it was considered that clostocin 0 acted upon the biosynthesis of nucleic acid as the first target. The mode of action of clostocin 0 was considered to be closely related to those of colicins El and K, and pyocins R and 28, and also that of colicin E2. However, there are some differences in mode of action between clostocin 0 and these bacteriocins. Pyocin $\mathrm{R}$ inhibits the biosynthesis of protein (Kaziro and Tanaka, 1965) and pyocin 28 inhibits strongly the biosynthesis of almost all macromolecules at the same grade (Ohnishi, 1969). Colicins E 1 and $\mathrm{K}$ inhibit such all abilities of sensitive organism as the biosynthesis of macromolecules, permeability and biosynthesis of ATP, but the respiratory ability is retained for considerable time (Nomura, 1964). Colicin E 2 causes remarkable DNA degradation [Holland and Holland, 1970; Yanai et al., 1973), and moreover, RNA and protein of $50 \mathrm{~S}$ and $30 \mathrm{~S}$ ribosomes of sensitive organism are degradated into low molecules (Nose and Mizuno, 1968; Nose et al., 1966). From these facts, it is concluded that clostocin 0 inhibits only biosynthesis of nucleic acid and shows a different type of mode of action from these bacteriocins.

Duckworth (1970), Fukuma and Kaji (1972) and Winkler and Duckworth (1971) reported that phage ghosts had shown the same action as bacteriocins. The ghosts of T4 phage cause not only the repression of permeability and the inhibition of biosynthesis of macromolecules but also remarkable inhibition of respiratory ability in infected organism. As the permeability and protein biosynthesis are strongly decreased at first by the infection of phage ghosts, it seems that their mode of action is not the same as that of clostocin 0.

The biosyntheses of nucleotides in cold TCA soluble was strongly inhibited by clostocin 0 infection, so this fact was considered to be closely related to the inhibition of nucleic acid biosynthesis and energy metabolism in clostocin O-infected organism. 


\section{ACKNOWLEDGEMENTS}

The authors would like to express their thanks to Mr. Osamu TosakaMihara, Mr. Koji Ueyama and Mr. Kuniyoshi Imafuku for their excellent assistance of this experiment.

This work is Part VIII of Bacteriocins of Nonpathogenic Colostridium Species and was supported in part by a Grant-in-Aid of Scientific Research from the Ministry of Education of Japan.

\section{REFERENCES}

Bowman, C. D., J. E. Dahlberg. T. Ikemura, J. Konisky and M. Nomura 1971 a Specific inactivation of $16 \mathrm{~S}$ ribosomal RNA induced by colicin E 3 in vivo. Proc. Natl. Acad. Sci. USA, $68: 964-968$

Bowman, C. D.. J. Sidikaro and M. Nomura 1971 b Specific inactivation of ribosomes by colicin E3 in vitro and mechanism of immunity in colicinogenic cells. Nature, $234: 133$ 137

Brock, T. D. and J. M. Davie 1963 Probable identity of a group D hemolysin with abacteriocine. J. Bactriol. $86: 708-712$

Davie. J. M. and T. D. Brock 1966 Action of streptolysin S, the group D hemolysin, and phospholipase $\mathrm{C}$ on whole cells and spheroplasts. J.Bacteriol., 91 : 595-600

de Graaf. F. K. and A. H. Stouthamer 1969 Mode of action of a bacteriocin produced by Enterobacter cloacae. J. Mol. Biol., 55 : xiii-xiv

de Graaf, F. K. and A. H. Stouthamer 1970 Isolation and properties of bacteriocin-tolerant mutants of Klebsiella edwardsii. J. Microbiol.Serol., $36: 217-226$

Duckworth, D. H. 1970 Biological activity of bacteriophage ghosts and "take-over" of host function by bacteriophage. Bacteriol. Rev., $34: 344-365$

Fields, K. L. and S. E. Luria 1969 Effects of colicins El and K on cellular metabolism. $J$. Bacteriol., $97: 64-77$

Fukuma, I. and A. Kaji 1972 Effect of bacteriophage ghost infection on protein synthesis in Escherichia coli.J. Virol., 10 : 713-720

Holland, I. B. 1963 Effect of bacteriocin preparation (Megacin C) on DNA synthesis in Bacillus megaterium. Biochem. Biophys. Res. Comm., $13: 246-150$

Holland, I. B. 1965 A bacteriocin specifically affecting DNA synthesis in Bacillus megaterium. J. Mol. Biol., 12 : 429-438

Holland, E. M. and I. B. Holland 1970 Induction of DNA breakdown and inhibition of cell division by colicinE2. Nature of some early steps in the process and properties of the E2-specific nuclease system. J. Mol. Biol., $64: 223-239$

Holland, I. B. and C. F. Roberts 1964 Some properties of a new bactcriocin formed by Bacillus megaterium. J. Gen. Microbiol., $35: 271-285$

Jacob, F.. L. Siminovitch et E. Wollman 1952 Sur la biosynthése d'une colicine et su son mode d'action. Annal. Inst. Pasteur, $83: 295-315$

Kato. F., S. Ogata and M. Hongo 1976 Killing activity of clostocin 0. Agric.Biol. Chem., 40: $1107-1111$

Kaziro, Y. and M. Tanaka 1965 Studies on the mode of action of pyocin. I. Inhibition of macromolecular synthesis in sensitive cells. J. Biochem., 57 : 689-695

Leloir, L. F. and C. E. Cardini 1957 Characterization of phosphorus compounds by acid lability. In "Methods of Enzymology", vol. III, ed. by S. P. Colowick and N. 0. Kaplan, Academic Press, Inc., New York, pp. 840-850

Levisohn, R., J. Konisky and M. Nomura 1968 Interaction of colicins with bacterial cells. 
IV. Immunity breakdown studied with colicins Ia and Ib. J. Bacteriol., 96 : 811-821

Luria, S. E. 1964 On the mechanism of action of colicin. Annal. Inst. Pasteur $107: 67-73$

Mizuno, S. and H. R. Whitely 1968 Nuclear Fraction of Bacillus subtilis as a template for ribonucleic acid synthesis. J.Bacteriol., $95: 1212-1237$

Nagel de Zwaig, R. 1969 Mode of action of colicin A. J.Bacteriol., 99 :913-914

Nomura, M. 1964 Mechanism of action of colicins. Proc. Natl.Acad. Sci. USA, 52 : 1514-1521

Nose, K., D. Mizuno and II. Ozeki 1966 Degradation of ribosomal RNA from Escherichia coli induced by colicin E2. Biochim. Biophys. Acta, $119: 636-638$

Nose, K. and D. Mizuno 1968 Degradation of ribosome in Escherichia coli cells treated with colicin E 2. J. Biochem., $64: 1-6$

Obinata, M. and D. Mizuno 1970 Mechanism of colicin E2-induced DNA degradation in Escherichia coli.Biochim. Biophys. Acta, 199:330-339

Ogata, S., F. Kato and M. Hongo 1976 Study on adsorption of inducible bacteriocin clostocin 0 toward sensitive bacteria. Agric. Biol.Chem., $40: 1093-1099$

Ogata, S., 0. Mihara, Y. Ikeda and M. Hongo 1972 Inducible phage tail-like particles of Clostridium sacchroperbutylacetonicum and its related strains. Agric. Biol.Chem., $36: 1413-$ 1421

Ogata, S. andM. Hongo 1974 Lysis induced by sodium ion and its relation to lytic enzyme systems in Clostridium saccharoperbutylacetonicum.J. Gen. Microbiol., 81 : 315323

Ohnishi, Y. 1969 Effects of pyocin 28 on sensitive bacteria. Acta Fukuoka Medica, 60 : 577 590

Reeves, P. 1972 The Bacteriocins. Springer-Verlag, Berlin, Heidelberg, New York, pp. 60-80

Ringrose, P.1970 Sedimentation analysis of DNA degradation products resulting from the action of colicin E2 on Escherichia coli. Biochim. Biophys. Acta, $213: 320-334$

Schallrr, K. and M. Nomura 1976 Colicin E2 is a DNA endonuclease. Proc. Natl. Acad. Sci. US A, 73 : 3989-3993

Senior, B. W. and I. B. Holland 1971 Effect of colicinE3 upon the $30 \mathrm{~S}$ ribosomal subunit of Escherichia coli. Proc. Natl. Acad. Sci. USA, $68: 959-963$

Winkler,H. H. and D.H. Duckworth 1971 Metabolism of T4 bacteriophage ghost-infected cells: Effect of bacteriophages and ghosts on the uptake of carbohydrate in Escherichia coli B.J. Bacteriol., $107: 253-267$

Yanai, A., T.Beppu and K. Arima 1973 Ribosome degradation in Escherichia collinduced by colicin E2. Biochem. Bophys. Res. Comm., $54: 1185-1190$ 